\title{
Implementasi Wireless Sensor Network untuk Otomatisasi Suhu Ruang dan Kelembaban Tanah pada Greenhouse Berbasis Web Server
}

\author{
Yogha Arieka Adnantha ${ }^{1}$, Wahyu Andhyka Kusuma ${ }^{2}$ \\ ${ }^{1,2}$ Teknik Informatika, Fakultas Teknik - Universitas Muhammadiyah Malang \\ 1'yogha.arieka@gmail.com, ${ }^{2}$ kusuma.wahyu.a@umm.ac.id
}

\begin{abstract}
Along with the increasing population of Indonesia which is also followed by the increasing rate of urbanization in the industrial sector, certainly affects the reduced agricultural sector to increase food needs. Greenhouse can be one solution to solve this problem, by utilize greenhouse our enviroment can be controlled and also protect the plants from outside interference. During this condition is still done manually both to measure the temperature or watering the plants. In this study the author developed a system to monitor and automate room temperature and soil moisture in greenhouse by utilizing Wireless Sensor Network (WSN) technology. The system consists of 1 node temperature and humidity chamber and 1 node of greenhouse soil moisture where each node is composed of arduino uno as its microcontroller, ESP8266 as Wi-Fi module, sensor, and relay. The results of monitoring and automation data will be sent to the web server by wireless, to make it easier for greenhouse farmers and monitoring their greenhouse. The results of this study can be found that the system is able to monitor and perform automatic control of temperature decrease, when the temperature reaches more than $28 \mathrm{C}$ and able to increase soil moisture automatically when the soil moisture is less than $40 \%$, in addition by using ESP8266 data monitoring and automation results can be sent to the web server but based on the test results obtained that the maximum range of data transmission is $\mathbf{5 0}$ meters from the node to the access point.
\end{abstract}

Keywords- WSN, ESP8266, DHT11, Soil muisturation, Automatication, Greenhouse.

\begin{abstract}
Abstrak- Seiring meningkatnya jumlah penduduk indonesia yang juga diikuti oleh peningkatan laju urbanisasi pada sektor industri, tentu berpengaruh terhadap berkurangnya sektor pertanian untuk memenuhi kebutuhan pangan yang semakin meningkat. Greenhouse atau rumah kaca bisa menjadi salah satu solusi untuk permasalahan ini, dengan memanfaatkan greenhouse kondisi lingkungan dapat dikendalikan sekaligus dapat melindungi tanaman dari gangguan luar. Selama ini pengkondisian lingkungan greenhouse masih dilakukan manual baik untuk mengukur suhu dan melakukan penyiraman tanaman. Pada penelitian ini penulis mengembangkan sistem untuk memonitoring dan otomatisasi suhu ruang dan kelembaban tanah pada greenhouse dengan memanfaatkan teknologi Wireless Sensor Network (WSN). Sistem terdiri dari 1 node suhu dan kelembaban ruang dan 1 node kelembaban tanah greenhouse dimana masing-masing node tersusun dari arduino uno sebagai mikrokontrolernya, ESP8266 sebagai modul Wi-Fi, sensor, dan relay. Data hasil monitoring dan otomatisasi akan dikirim ke web server secara wireless sehingga memudahkan petani greenhouse untuk memantau greenhouse miliknya. Hasil dari penelitian ini didapatkan bahwa sistem mampu untuk memonitoring dan melakukan kontrol otomatis penurunan suhu ruang greenhouse ketika suhu mencapai lebih dari 28C dan mampu untuk meningkatkan kelembaban tanah secara otomatis ketika kelembaban tanah kurang dari 40\%, selain itu dengan memanfaatkan ESP8266 data hasil monitoring dan otomatisasi dapat dikirim ke web server tetapi berdasarkan hasil pengujian didapatkan bahwa jangkauan maksimal pengiriman data yaitu 50 meter dari node ke access point.
\end{abstract}

Kata kunci- WSN, ESP8266, DHT11, Kelembaban Tanah, Otomatisasi, Greenhouse.

\section{PENDAHULUAN}

Seiring berkembangnya jumlah penduduk Indonesia, permintaan akan bahan pangan juga ikut meningkat. Kondisi ini juga diikuti oleh peningkatan laju urbanisasi pada sektor industri, sehingga pada sektor pertanian juga semakin berkurang. Selain itu, peningkatan jumlah hunian penduduk juga mempengaruhi sektor pertanian dimana terjadi penurunan jumlah lahan produktif untuk sektor pertanian. Salah satu cara untuk memenuhi kebutuhan pangan yang semakin meningkat dengan lahan pertanian yang semakin menurun yaitu dengan menggunakan teknologi greenhouse.
Greenhouse atau rumah kaca merupakan suatu bangunan yang terdiri dari bahan kaca maupun plastik tebal dan menutupi seluruh dinding dan atap bangunan tersebut[1]. Greenhouse berfungsi untuk melindungi tanaman dari gangguan luar seperti hujan deras, angin kencang dan kelembaban yang tinggi, dengan menggunakan greenhouse kegiatan pertanian tidak tergantung pada kondisi musim yang terjadi. Greenhouse dapat digunakan untuk mengendalikan kondisi lingkungan tanaman di dalamnya, adapun parameter yang mempengaruhi kondisi lingkungan tersebut antara lain adalah suhu, kelembaban, pencahayaan, kadar karbondioksida dan sebagainya[1][2]. 
Selama ini untuk pengkondisian lingkungan masih dilakukan secara manual dengan mengukur suhu menggunakan termometer dan melakukan penyiraman tanaman secara manual untuk menjaga kelembaban tanah greenhouse. Hal ini tentu akan menjadi masalah tersendiri bagi masyarakat yang ingin memiliki greenhouse dirumahnya tetapi disisi lain juga memiliki kesibukan tersendiri karena pekerjaannya.

Seiring kemajuan teknologi terdapat solusi untuk permasalahan tersebut yaitu dengan memanfaatkan mikrokontroler arduino uno dan sensor yang berfungsi untuk memantau kondisi lingkungan pada greenhouse. Ada beberapa penelitian terdahulu yang memanfaatkan mikrokontroler arduino uno dan sensor, seperti untuk pengontrolan suhu ruang[3], monitoring listrik prabayar[4], dan kontrol air nutrisi aquaponik[5]. Penelitian sebelumnya terkait greenhouse dengan memanfaatkan sensor juga pernah dikembangkan[1][6]. Tetapi pada penelitian tersebut, sistem hanya dapat melakukan monitoring kondisi greenhouse. Penelitian berikutnya dikembangkan sistem yang dapat mengontrol kondisi greenhouse berdasarkan parameter suhu[2]. Pada penelitian tersebut sistem hanya dapat mengkontrol suhu dan data hanya ditampilkan di layar LCD 16X2 sehingga pemilik greenhouse perlu datang ke lokasi untuk memantau kondisi greenhouse dan melakukan penyiraman secara manual untuk menjaga kelembaban tanah.

Berdasarkan permasalahan tersebut Wireless Sensor Network (WSN) bisa menjadi salah satu solusi, dengan memanfaatkan teknologi ini memungkinkan pengiriman data hasil akuisisi kondisi greenhouse secara nirkabel dari arduino ke web server yang kemudian disimpan di database sehingga petani greenhouse dapat memantau secara real-time kondisi greenhouse setiap waktu.

Wireless Sensor Network (WSN) merupakan jaringan nirkabel yang terdiri dari beberapa alat sensor yang saling bekerja sama untuk memonitor fisik dan kondisi lingkungan seperti temperatur, air, polusi udara dan lainlain[7]. Banyak penelitian sebelumnya yang telah membahas tentang implementasi dari teknologi WSN ini, diantaranya yaitu seperti sistem untuk monitoring suhu dan kelembaban pada lahan tanaman jarak dan sistem untuk kontrol dan monitoring $\mathrm{PH}$ tanah pada tanaman kentang[8]. Penelitian sebelumnya terkait WSN pada greenhouse juga pernah dikembangkan[9][10]. Pada penelitian tersebut Sistem WSN yang digunakan menggunakan perangkat Xbee pro sebagai modul $\mathrm{Wi}-\mathrm{Fi}$ yang berjalan dengan protokol ZigBee. Penggunaan perangkat Xbee pada penelitian ini dirasa cukup mahal, apalagi dalam penerapan greenhouse jika petani ingin melakukan penambahan greenhouse tentu akan menjadi beban tersendiri. Oleh karena itu pada penelitian ini penulis menggunakan ESP8266 yang memiliki harga jauh lebih murah dari pada Xbee Pro.

Penelitian ini akan membahas mengenai pengembangan sistem untuk monitoring dan otomatisasi suhu ruang dan kelembaban tanah pada greenhouse dengan memanfaatkan WSN untuk mengirimkan data hasil monitoring dan otomatisasi ke web server. Sistem yang dikembangkan terdiri dari 1 node untuk monitoring dan otomatisasi suhu ruang serta 1 node untuk monitoring dan otomatisasi kelembaban tanah, masing-masing node merupakan mikrokontroler arduino uno yang dihubungkan menggunakan topologi star secara nirkabel dengan menggunakan ESP8266 dan protokol HTTP untuk komunikasi data dari tiap node ke web server.

\section{METODE PENELITIAN}

\section{A. METODOLOGI PENELITIAN}

Metodologi penelitian yang digunakan dalam pengembangan sistem ini adalah sebagai berikut:

\section{1) Studi Kepustakaan}

Tahap ini dilakukan untuk mendapatkan materimateri terkait pengembangan sistem yang akan dibangun menggunakan arduino uno dan ESP8266. Hal ini berupaya agar tahap penelitian tidak menyimpang dari prosedur dan ketentuan yang ada.

\section{2) Analisa Dari Materi Yang Terkumpul}

Membuat rencana awal terhadap kebutuhan akan hardware dan software yang akan diterapkan, serta mengumpulkan manfaat apa saja yang didapat dari sistem WSN menggunakan arduino uno dan ESP8266.

\section{3) Perancangan Sistem}

Membuat keseluruhan sistem secara umum dalam bentuk simulasi yang menggambarkan jaringan WSN menggunakan model topologi star yang dikembangkan untuk monitoring dan otomatisasi kondisi greenhouse.

\section{4) Implementasi Sistem}

Mulai melakukan tahap pengembangan sistem berdasarkan rancangan yang telah dibuat, pada tahap ini dilakukan integrasi hardware arduino uno, sensor dan ESP8266 serta melakukan pengkodean untuk arduino uno dan pengembangan web server.

\section{5) Pengujian Sistem}

Melakukan pengujian sistem secara keseluruhan berdasarkan beberapa paramater tertentu. Antara lain integritas data yang dikirim, ketepatan kontrol otomatis dan pengaruh jangkauan transmisi terhadap integritas data.

\section{6) Pembuatan Laporan}

Menyusun laporan tertulis dengan tujuan sebagai bentuk dokumentasi pengerjaan sistem dan dapat digunakan untuk pengembangan pada penelitian selanjutnya. 


\section{B. DESAIN SISTEM KESELURUHAN}

Sistem dikembangkan menggunakan mikrokontroler arduino uno sebagai sistem pusat monitoring dan otomatisasi, dimana sistem terdiri dari 1 node untuk monitoring dan otomatisasi suhu ruang (lihat gambar 1) serta 1 node untuk monitoring dan otomatisasi kelembaban tanah (lihat gambar 2). Sistem terhubung dengan access point secara wireless menggunakan ESP8266 sehingga membentuk topologi star.

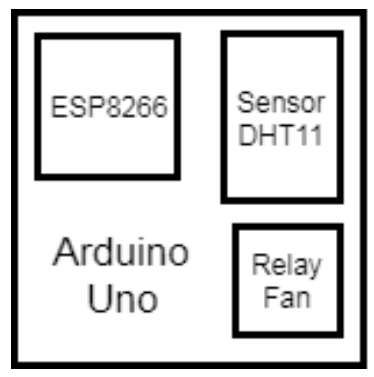

Gambar 1. Susunan Perangkat Pada Node Suhu Ruang

Pada gambar 1 menunjukan rangkaian dari node untuk monitoring dan kontrol suhu otomatis. Dimana jika suhu melebihi batas yang ditentukan maka akan mengaktifkan relay yang terhubung ke kipas angin, sehingga kipas akan menyala dan menurunkan suhu sampai batas suhu normal yang ditentukan. Data hasil monitoring dan otomatisasi akan dikirim ke web server menggunakan ESP8266 yang telah terintegrasi dengan Arduino Uno.

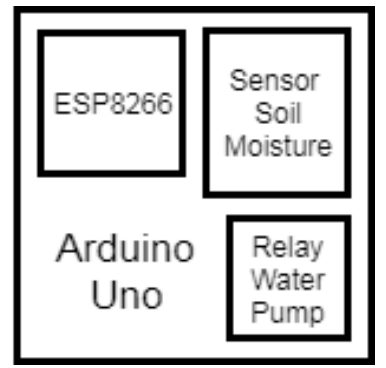

Gambar 2. Susunan Perangkat Pada Node Kelembaban Tanah

Pada gambar 2 menunjukan rangkaian dari node untuk monitoring dan kontrol kelembaban otomatis. Dimana jika kelembaban melebihi batas yang ditentukan maka akan mengaktifkan relay yang terhubung ke pompa air, sehingga pompa air akan menyala dan mengalirkan air dan akan berhenti sampai batas kelembaban normal yang ditentukan. Data hasil monitoring dan otomatisasi akan dikirim ke web server menggunakan ESP8266 yang telah terintegrasi dengan Arduino Uno.

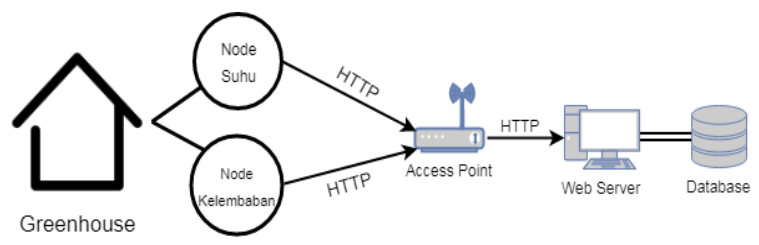

Gambar 3. Arsitektur Sistem Keseluruhan

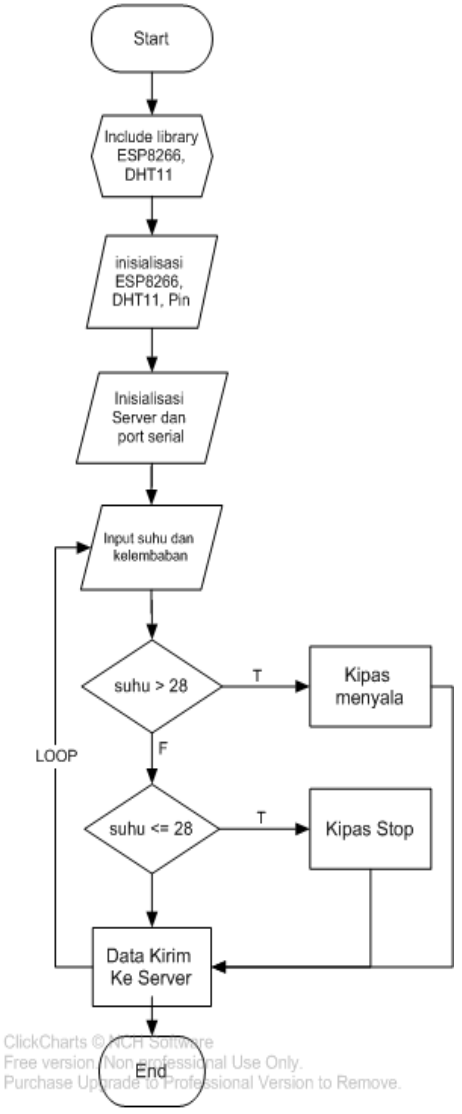

Gambar 4. Flowchart Node Monitoring Dan Otomatisasi Suhu Ruang

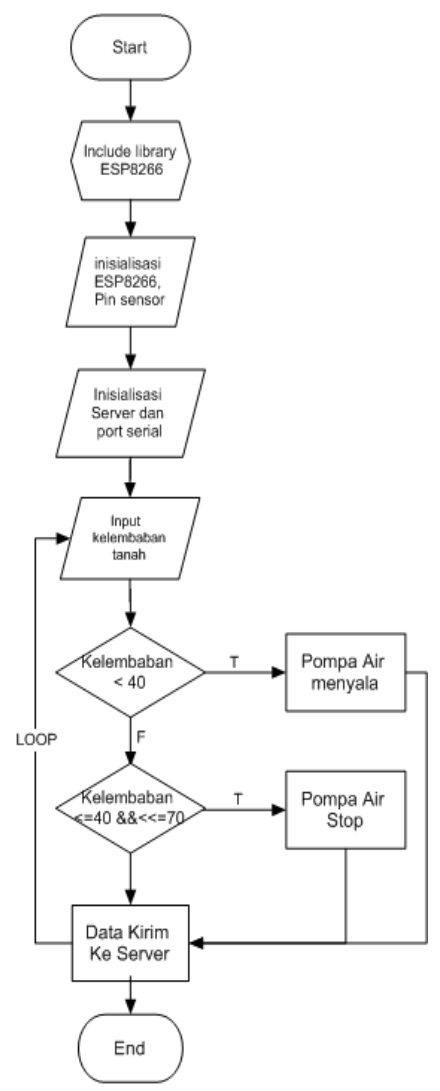

Gambar 5. Flowchart Node Monitoring Dan Otomatisasi Kelembaban Tanah 
Pada Gambar 3 menunjukan bahwa node mengirimkan data hasil monitoring dan otomatisasi menggunakan protokol HTTP sebagai metode pengiriman data ke web server yang kemudian data akan disimpan di database. Karena terdapat 2 node pada greenhouse yang mengirimkan data, agar tidak terjadi tabrakan data saat pengiriman. Pada penelitian ini penulis akan memberikan interval atau jeda waktu pengiriman antara node suhu dan node kelembaban. Gambar 4 dan 5 merupakan flowchart alur program pada tiap-tiap node dimana monitoring dan kontrol otomatis dilakukan terpusat di arduino uno tiap masing-masing node.

Dengan model seperti ini diharapkan dapat menyelesaikan permasalahan pada penelitian sebelumnya sehingga memudahkan petani greenhouse tanpa perlu datang ke lokasi untuk memantau keadaan greenhouse serta tidak perlu melakukan penyiraman secara manual.

\section{PENGUJIAN SISTEM}

Pengujian sistem sangat diperlukan guna mengetahui apakah sistem yang dikembangkan sudah sesuai dengan rancangan dan dapat bekerja dengan baik serta mengetahui parameter apa saja yang mempengaruhi sistem. Berikut beberapa pengujian yang dilakukan pada penelitian ini:

\section{1) Pengujian Node Sistem}

Pengujian dilakukan pada masing-masing node, dimana tujuan dari pengujian ini adalah untuk mengetahui apakah arduino uno dan sensor sudah terintegrasi dengan benar dan dapat melakukan monitoring dan otomatisasi. Pengujian dilakukan dengan melakukan monitoring kondisi greenhouse sesuai dengan fungsi masing-masing node dan apakah tiap node tersebut dapat melakukan kontrol otomatis sesuai dengan kondisi dari inputan sensor.

\section{2) Pengujian Pengiriman Data Hasil Monitoring}

Pengujian ini berguna untuk mengetahui kelengkapan data yang dikirim ke web server. Pada penelitian ini akan dilakukan percobaan monitoring dan otomatisasi pada arduino uno kemudian mengirimkan data hasil monitoring dan otomatisasi ke web server secara wireless menggunakan ESP8266.

\section{3) Pengujian Jangkauan Transmisi Sistem}

Pengujian ini bertujuan untuk mengetahui pengaruh dari jangkauan node terhadap pengiriman data ke web server. Pada pengujian ini akan dilakukan pengiriman data dari tiap node ke web server dengan mengacu jarak antara node dengan access point. Melalui pengujian ini pula dapat diketahu performansi jangkauan dari ESP8266.

\section{HASIL DAN PEMBAHASAN}

\section{A. IMPLEMENTASI NODE PADA SISTEM MONITORING DAN OTOMATISASI GREENHOUSE \\ 1) Implementasi Node Suhu Dan Kelembaban Ruang Greenhouse}

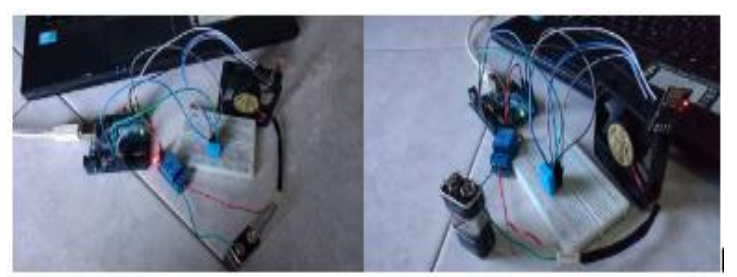

Gambar 6. Rancangan Node Monitoring Dan Otomatisasi Suhu Dan Kelembaban Ruang Pada Greenhouse

Gambar 6 merupakan bentuk fisik dari node suhu dan kelembaban ruang greenhouse yang terdiri dari arduino uno sebagai pengolah data, DHT11 sebagai sensor suhu dan kelembaban, relay sebagai kontrol untuk menyalakan kipas jika sensor mendeteksi suhu lebih dari batas maksimum yang telah ditentukan yaitu 28C dan akan berhenti ketika suhu kurang dari $28 \mathrm{C}$, kemudian data hasil monitoring dan kontrol akan dikirim ke web server menggunakan ESP8266 sebagai modul Wi-Fi.

\section{2) Implementasi Node Kelembaban Tanah Greenhouse}

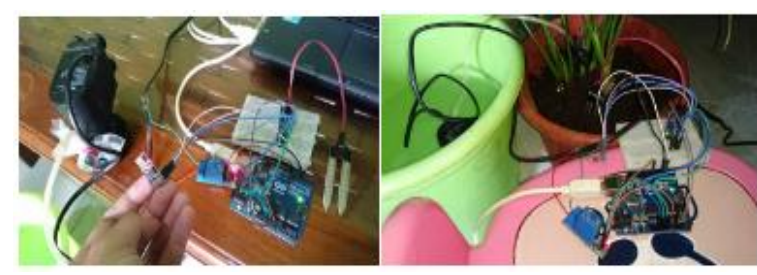

Gambar 7. Rancangan Node Monitoring Dan Otomatisasi Kelembaban Tanah Pada Greenhouse

Seperti halnya pada node suhu dan kelembaban ruang, gambar 7 merupakan bentuk fisik dari node kelembaban tanah pada greenhouse yang berfungsi untuk memantau dan melakukan kontrol otomatis terhadap kelembaban tanah jika sensor mendeteksi bahwa kelembaban tanah kurang dari batas minimum kelembaban tanah yang telah ditentukan yaitu $40 \%$. Sesor kelembaban tanah yang digunakan pada penelitian ini sendiri memiliki output berupa data analog yang kemudian dilakukan konversi ke persen untuk memudahkan pembacaan data dimana jika data persen terdeteksi kurang dari $40 \%$ maka arduino akan mengaktifkan relay yang kemudian menyalakan pompa air dan akan berhenti hingga kelembaban lebih dari batas yang ditentukan. Data hasil monitoring dan kontrol kemudian akan 
dikirimkan ke web server menggunakan ESP8266 sebagi modul Wi-Fi.

B. HASIL PENGUJIAN SISTEM

1) Pengujian Node Suhu dan Kelembaban Ruang Greenhouse

Pengujian ini dilakukan untuk mengetahui apakah sensor dan kontroler telah terintegrasi dengan benar pada arduino uno. Pengujian dilakukan dengan menjalankan node untuk monitoring dan otomatisasi suhu dan kelembaban ruang greenhouse dimana data tersebut dapat dilihat pada serial monitor (lihat gambar 8)

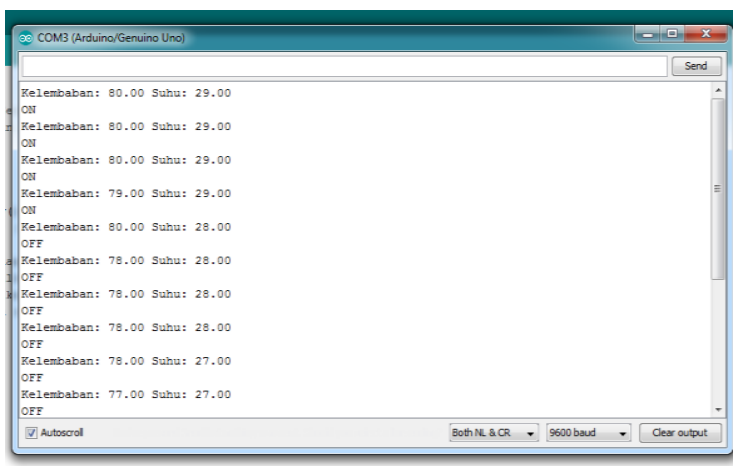

Gambar 8. Serial Monitor Hasil Monitoring Dan Otomatisasi Suhu Dan Kelembaban Ruang

Tabel 1. Pengujian Monitoring Dan Kontrol Otomatis Pada Node Suhu Dan Kelembaban Ruang

\begin{tabular}{|c|c|c|c|}
\hline $\begin{array}{c}\text { Pengujian } \\
\text { Ke- }\end{array}$ & $\begin{array}{c}\text { Suhu } \\
\text { (C) }\end{array}$ & $\begin{array}{c}\text { Kelembaban } \\
\text { (RH) }\end{array}$ & $\begin{array}{l}\text { Status } \\
\text { Kipas }\end{array}$ \\
\hline 1 & 29 & 80 & $\mathrm{ON}$ \\
\hline 2 & 29 & 80 & ON \\
\hline 3 & 29 & 80 & ON \\
\hline 4 & 29 & 79 & ON \\
\hline 5 & 28 & 80 & OFF \\
\hline 6 & 28 & 78 & OFF \\
\hline 7 & 28 & 78 & OFF \\
\hline 8 & 28 & 78 & OFF \\
\hline 9 & 27 & 78 & $\overline{\text { OFF }}$ \\
\hline 10 & 27 & 77 & OFF \\
\hline 11 & 27 & 77 & OFF \\
\hline 12 & 27 & 77 & OFF \\
\hline 13 & 27 & 77 & OFF \\
\hline 14 & 27 & 77 & OFF \\
\hline 15 & 26 & 78 & $\overline{\mathrm{OFF}}$ \\
\hline
\end{tabular}

Pengujian Node Suhu dan Kelembaban Ruang

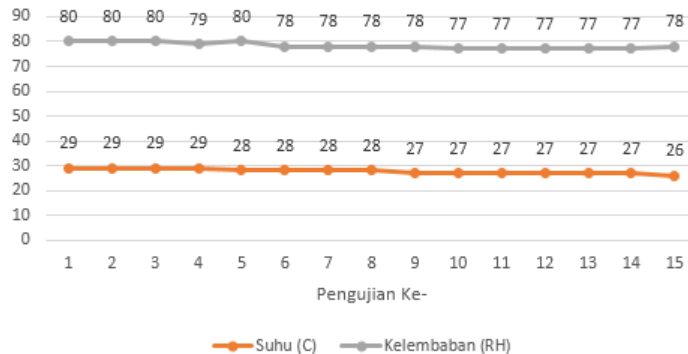

Gambar 9. Grafik Pengujian Node Suhu Dan Kelembaban Ruang Pada Greenhouse

Tabel 1 dan gambar 9 merupakan hasil dari pengujian node untuk monitoring dan otomatisasi suhu dan kelembaban ruang pada greenhouse. Hasil pengujian ini didapatkan bahwa sistem mampu untuk mendeteksi dan melakukan kontrol otomatis ketika suhu melebihi batas maksimum yang telah ditentukan dan berhenti ketika ruang greenhouse turun mencapai ambang batas yang telah ditentukan.

2) Pengujian Node Kelembaban Tanah Greenhouse

Pengujian ini dilakukan untuk mengetahui apakah sensor dan kontroler telah terintegrasi dengan benar pada arduino uno. Pengujian dilakukan dengan menjalankan node untuk monitoring dan otomatisasi kelembaban tanah pada greenhouse dimana data tersebut dapat dilihat pada serial monitor (lihat gambar 10).

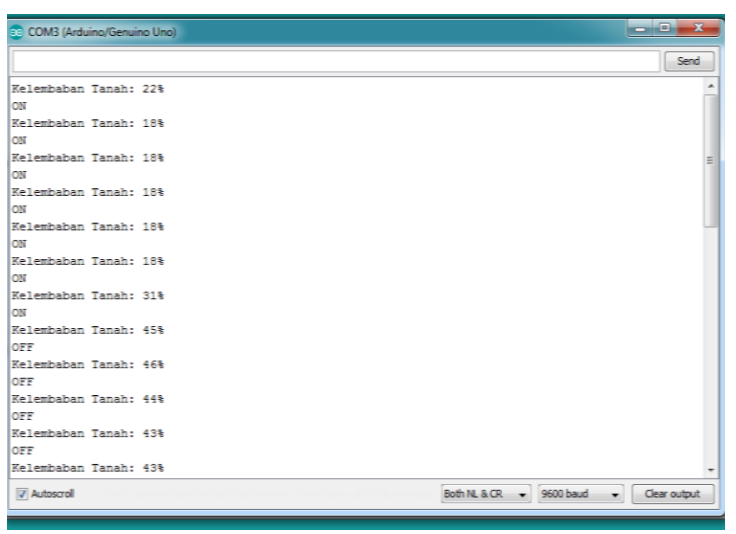

Gambar 10. Serial Monitor Hasil Monitoring Dan Otomatisasi Kelembaban Tanah.

Tabel 2. Pengujian Monitoring Dan Kontrol Otomatis Pada Node Kelembaban Tanah

\begin{tabular}{ccc}
\hline $\begin{array}{c}\text { Pengujian } \\
\text { Ke- }\end{array}$ & $\begin{array}{c}\text { Kelembaban } \\
\text { Tanah }(\%)\end{array}$ & $\begin{array}{c}\text { Status Pompa } \\
\text { Air }\end{array}$ \\
\hline 1 & 22 & ON \\
\hline 2 & 18 & ON \\
\hline 3 & 18 & ON \\
\hline 4 & 18 & ON
\end{tabular}




\begin{tabular}{ccc}
\hline $\begin{array}{c}\text { Pengujian } \\
\text { Ke- }\end{array}$ & $\begin{array}{c}\text { Kelembaban } \\
\text { Tanah }(\%)\end{array}$ & $\begin{array}{c}\text { Status Pompa } \\
\text { Air }\end{array}$ \\
\hline 5 & 18 & ON \\
\hline 6 & 18 & ON \\
\hline 7 & 31 & OFF \\
\hline 8 & 45 & OFF \\
\hline 9 & 46 & OFF \\
\hline 10 & 44 & OFF \\
\hline 11 & 43 & OFF \\
\hline 12 & 43 & OFF \\
\hline 13 & 51 & OFF \\
\hline 14 & 49 & OFF \\
\hline 15 & 46 & \\
\hline
\end{tabular}

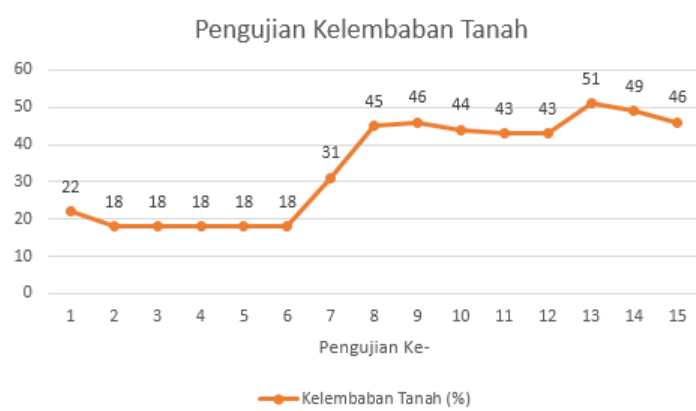

Gambar 11. Grafik Pengujian Node Kelembaban Tanah Pada Greenhouse

Tabel 2 dan gambar 11 merupakan hasil dari pengujian node untuk monitoring dan otomatisasi kelembaban tanah pada greenhouse. Hasil pengujian ini didapatkan bahwa sistem mampu untuk mendeteksi dan melakukan kontrol otomatis ketika kelembaban tanah kurang dari batas minimum kelembaban yang telah ditentukan dan berhenti ketika kelembaban tanah greenhouse mencapai ambang batas yang telah ditentukan.

\section{3) Pengujian Pengiriman Data Suhu dan} Kelembaban Ruang Greenhouse

Pengujian ini dilakukan dengan tujuan untuk mengetahui kelengkapan data yang dikirim dari node suhu dan kelembaban ruang greenhouse ke web server. Pengujian dilakukan dengan mengirimkan data hasil monitoring dan otomatisasi menggunakan ESP8266 sebagai modul Wi-Fi.

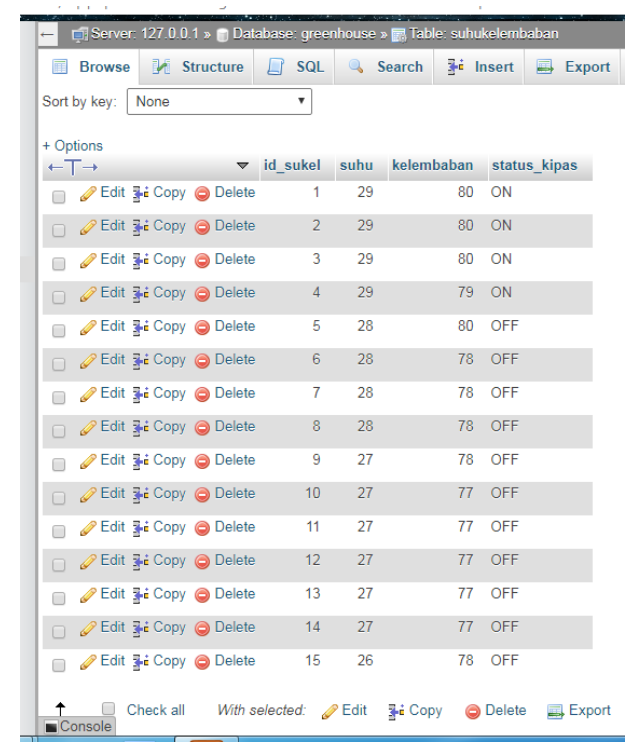

Gambar 12. Database Hasil Monitoring Dan Otomatisasi Suhu Dan Kelembaban Ruang

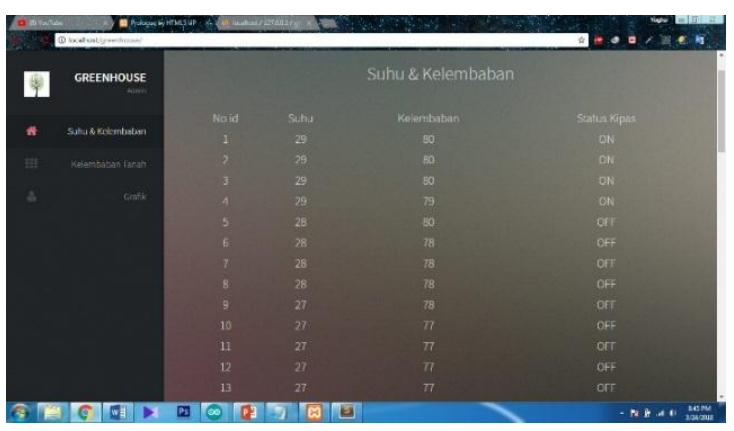

Gambar 13. Tampilan Data Pada Web Server Hasil Monitoring Dan Otomatisasi Suhu Dan Kelembaban Ruang

Hasil pengujian ini didapatkan bahwa data hasil monitoring dan otomatisasi suhu dan kelembaban ruang greenhouse berhasil terkirim dengan lengkap dan tersimpan di database pada web server seperti yang ditampilkan pada gambar 12, kemudian datadata tersebut dapat diakses di web server yang tampilkan pada gambar 13 .

\section{4) Pengujian Pengiriman Data Kelembaban Tanah Greenhouse}

Pengujian ini dilakukan dengan tujuan untuk mengetahui kelengkapan data yang dikirim dari node kelembaban tanah greenhouse ke web server. Pengujian dilakukan dengan mengirimkan data hasil monitoring dan otomatisasi menggunakan ESP8266 sebagai modul Wi-Fi. 


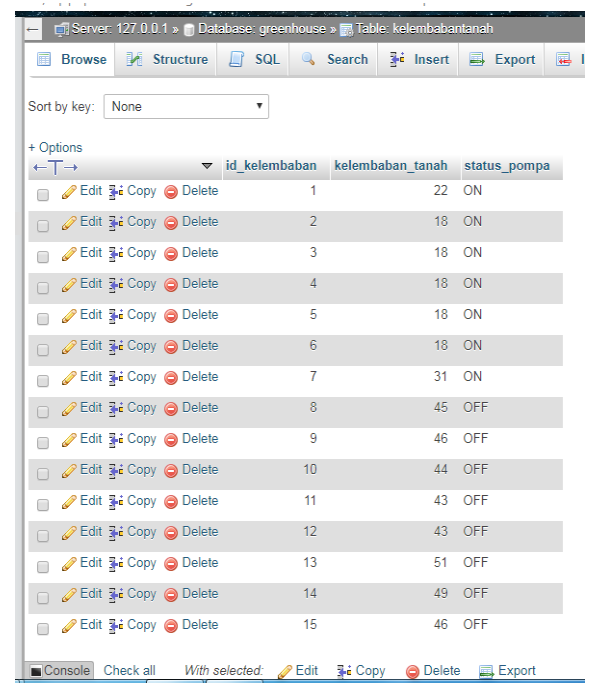

Gambar 14. Database Hasil Monitoring Dan Otomatisasi Kelembaban Tanah

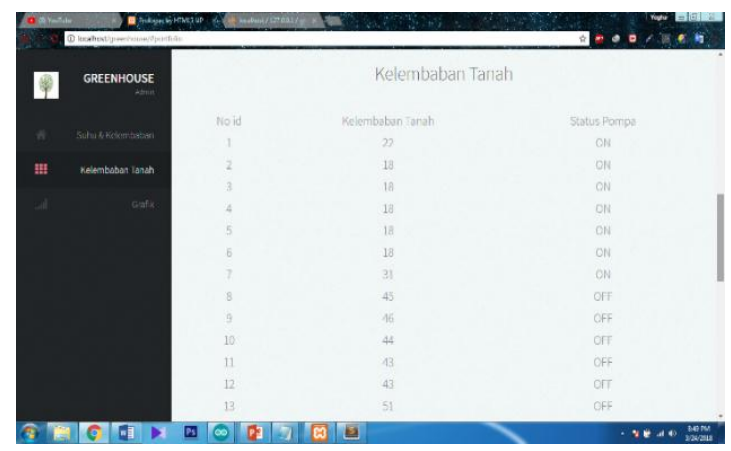

Gambar 15. Tampilan Data Pada Web Server Hasil Hasil Monitoring Dan Otomatisasi Kelembaban Tanah

Hasil pengujian ini didapatkan bahwa data hasil monitoring dan otomatisasi kelembaban tanah greenhouse berhasil terkirim dengan lengkap dan tersimpan di database pada web server seperti yang ditampilkan pada gambar 14, kemudian data-data tersebut dapat diakses di web server yang tampilkan pada gambar 15 .

\section{5) Pengujian Jangkauan Transmisi Sistem}

Pengujian ini dilakukan dengan tujuan untuk mengetahui seberapa jauh jangkauan pengiriman data menggunakan ESP8266. Pengujian dilakukan dengan mengirimkan data ke web server dan mengukur berbagai variasi jarak antara node dan access point.

Tabel 3. Pengujian Transmisi Data Antara Node Dengan Access

\begin{tabular}{ccc}
\hline $\begin{array}{c}\text { Pongujian } \\
\text { Ke- }\end{array}$ & Jarak & $\begin{array}{c}\text { Hasil } \\
\text { Pengiriman }\end{array}$ \\
\hline 1 & 5 & Terkirim \\
\hline 2 & 10 & Terkirim \\
\hline 3 & 20 & Terkirim
\end{tabular}

\begin{tabular}{ccc}
\hline $\begin{array}{c}\text { Pengujian } \\
\text { Ke- }\end{array}$ & Jarak & $\begin{array}{c}\text { Hasil } \\
\text { Pengiriman }\end{array}$ \\
\hline 4 & 30 & Terkirim \\
\hline 5 & 40 & Terkirim \\
\hline 6 & 50 & Terkirim \\
\hline 7 & 60 & Tidak Terkirim \\
\hline 8 & 70 & Tidak Terkirim \\
\hline 9 & 80 & Tidak Terkirim \\
\hline 10 & 90 & Tidak Terkirim \\
\hline
\end{tabular}

Tabel 3 merupakan hasil dari pengujian ini dimana didapatkan bahwa jarak 5 sampai 50 meter data masih dapat terkirim ke web server, tetapi ketika jarak 60 meter dari access point data sudah tidak dapat terkirim ke web server.

\section{IV.PENUTUP}

\section{A. KESIMPULAN}

Berdasarkan pengujian yang telah dilakukan hasil yang didapat dari penelitian ini yaitu sistem dapat berjalan dengan baik dimana node suhu dan kelembaban mampu untuk mendeteksi suhu dan kelembaban secara efektif dan dapat melakukan otomatisasi penurunan suhu jika suhu melebihi batas maksimum yang ditentukan yaitu 28C dimana pada pengujian yang dilakukan suhu awal terdeteksi yaitu 29C kemudian turun hingga mencapai 27C. Begitu pula pada node kelembaban tanah, sensor mampu untuk mendeteksi tingkatan kelembaban tanah dan kemudian melakukan kontrol otomatis untuk meningkatkan kelembaban tanah jika kelembaban kurang dari batas yang telah ditentukan yaitu $40 \%$ dimana pada pengujian menunjukan nilai kelembaban awal yaitu $22 \%$ dan meningkat hingga mencapai nilai rata-rata $46 \%$. Dengan memaanfaatkan ESP8266, arduino uno dapat mengirimkan data hasil monitoring dan otomatisasi ke web server sehingga memudahkan dalam pemantauan kondisi greenhouse dari manapun dan kapanpun. Tetapi, berdasarkan pengujian jangkauan transmisi didapatkan bahwa jarak maksimum antara node dengan access point adalah 50 meter, dimana jika jarak lebih dari itu maka data tidak dapat terkirim ke web server.

\section{B. SARAN}

Berdasarkan hasil dari penelitian ini, penulisan memberikan beberapa saran yang dapat dikembangkan untuk penelitian berikutnya yaitu sebagai berikut:

1. Menambahkan pengolahan data hasil akuisisi tersebut menggunakan algoritma tertentu yang cocok untuk mendukung keputusan pengkondisian greenhouse. Seperti algoritma fuzzy dan sebagainya.

2. Menggunakan modul wireless ZigBee untuk dibandingkan efektifitasnya dengan ESP8266 yang digunakan pada penelitian ini. 
3. Mengembangkan aplikasi mobile untuk pemantauan dan kontrol pada greenhouse.

V. REFERENSI
[1] R. R. Prambayun and Sumarna, "Otomatisasi Pengendalian Suhu Pada Greenhouse,” J. Fis., vol. 7, no. 5, pp. 1-9, 2016.

[2] H. S. Nida, "Prototype Sistem Multi-Telemetri Wireless untuk Mengukur Suhu Udara Berbasis Mikrokontroler ESP8266 pada Greenhouse," Kinetik, vol. 2, no. 3, pp. 217-226, 2017.

[3] D. Prihatmoko, "Perancangan dan implementasi pengontrol suhu ruangan berbasis mikrokontroller arduino uno," SIMETRIS, vol. 7, no. 1, pp. 117-122, 2016.

[4] D. Risqiwati, "Rancang Bangun Sistem Monitoring Listrik Prabayar dengan Menggunakan Arduino Uno," Kinetik, vol. 1, no. 2, pp. 47-54, 2016.

[5] M. A. Fahmi, W. I. Aldhi, G. N. Abdul, and W. A. Sugiharto, "Sistem Monitoring Dan Controlling Air Nutrisi Aquaponik Menggunakan Arduino Uno Berbasis Web Server," KINETIK, vol. 1, no. 1, pp. 3946, 2016.

[6] H. Yanti, A. Putri, A. Tusi, and B. Lanya, "Greenhouse Berbasis Mikrokontroler Arduino Design of Micro Climate Data Acquisition System Based Microcontroller Arduino on Green House," J. Tek. Pertan. Lampung, vol. 4, no. 1, pp. 57-64, 2014.

[7] K. W. Pambudi, Jusak, and P. Susanto, "RANCANG BANGUN WIRELESS SENSOR NETWORK UNTUK MONITORING SUHU DAN KELEMBABAN PADA LAHAN TANAMAN JARAK," J. Control Netw. Syst., vol. 4, no. 1, pp. 3138, 2015.

[8] A. W. Wicaksono, E. R. Widasari, and F. Utaminingrum, "Implementasi Sistem Kontrol dan Monitoring pH pada Tanaman Kentang Aeroponik secara Wireless," J-Ptiik, vol. 1, no. 5, pp. 386-398, 2017.

[9] I. Lamprinos, M. Charalambides, and M. Chouchoulis, "Greenhouse Monitoring System Based on a Wireless Sensor Network," Int. Electron. Conf. Sensors Appl., no. November, 2015.

[10] J. Zhou, X. Wang, X. Wang, W. Zou, and J. Cai, "Greenhouse Monitoring and Control System Based on Zigbee," Proc. 2nd Int. Conf. Comput. Sci. Electron. Eng. (ICCSEE 2013), no. Iccsee, pp. 2361-2364, 2013. 